\title{
Studies on Physical and Microbial Parameters of Bovine Colostrum Powder
}

\author{
N. Sahana*, D. Ramasamy, T.R. Pugazhenthi and I. Manikkavasagan \\ Food Technology, Tamil Nadu Veterinary and Animal Sciences University \\ College of food and Dairy Technology, Koduveli, Chennai-600052, India \\ *Corresponding author
}

\section{A B S T R A C T}

\section{Ke ywords \\ Colostrum, \\ Colostrum powder, Physical parameter, Microbial parameter \\ Article Info \\ Accepted: \\ 15 July 2018 \\ Available Online: \\ 10 August 2018}

This study investigates the physical and microbial parameters of bovine colostrum powder. Colostrum is the first mammary secretion for $24-48$ hours after parturition and is a complex fluid rich in immune factors and growth factors. Studies have indicated that the immune boosting properties of bovine colostrum are beneficial for human beings with no reports of allergic or anaphylactic reactions. Colostrum powder was prepared by spray drying the whole colostrum. Physical and Microbial parameters were analyzed in colostrum powder. The total viable count found to be increased as the advancement of storage and coliforms were not detected. While comparing the water activity on initial and final day no changes were observed. With regard to physical parameters viz. texture analysis, insolubility index and bulk density no difference was found between cow and buffalo colostrum powder. Storage study of colostrum powder was carried out up to 6 months period

\section{Introduction}

In the recent days, the development of a new product which is rich in protein, vitamins and mineral content and also have therapeutic values are at a high demand among the consumers. The global consumers are more concerned about the nutrition of food what they intake than the taste of the food. Nowadays, high calorie foods are mostly avoided even by the younger generations. The importance of new product development and the role of food engineers and the nutritionists towards the development of nutritious food is at a rapid growth. The demand of the consumer towards healthy food has made the professionalists to move towards the new product development. As of now the only available immunoglobulin rich product is colostrum which is used in prevention and treatment of disease.

Colostrum is the secretion of the mammary gland immediately after parturition and contains a high concentration of Immunoglobulin (Tom R. Philips, 1998). Colostrum is the most persuasive natural immune booster known to science apart from a source of nutrients (contains more protein, 
immunoglobulins (Igs), non-protein nitrogen (NPN), fat, ash, vitamins and minerals than does normal milk) (Xanthou et al., 1995; Xu, 1996; Quigley and Drewry, 1998). Available evidence suggests a beneficial effect of supplementation of bovine colostrum in improving body composition, athletic performance, diarrhoea in person with immune deficiency syndromes, NSAID (Nonsteroidal induced gastrointestinal disturbances and aspects of the acute phase response that occur secondary to surgery (Kelly, 2003).

Concerning on the surplus amount of colostrum which is rich in immunoglobulin, a rare substance found in naturally occurring material, the excess amount of colostrum could be utilized for the production of colostrum powder rich in immunoglobulin $\mathrm{G}$.

Spray drying is fast and energy efficient compared to other drying methods (like, freeze drying and microwave evaporation). In this method, under controlled conditions, evaporation maintains low droplet temperature, $20-30{ }^{\circ} \mathrm{C}$ lower than outlet air temperature in concurrent system (Carid, 2003), which can avoid heat damage to the bioactive components (Chelack et al., 1993).

Hence this study is envisaged to investigate the physical and microbial properties of spary dried cow and buffalo colostrum.

\section{Materials and Methods}

Buffalo and cow colostrum were collected from the Community Cattle Care Centre of CFDT, Koduveli, Government Instructional Livestock Farm Complex (ILFC), Madhavaram, Post-Graduate Research Institute in Animal Sciences (PGRIAS), Kattupakkam of Tamilnadu Veterinary and Animal Sciences University (TANUVAS) and Private farms. Colostrum samples were collected for 2 consecutive days immediately after parturition from both cow and buffalo. After collection, the colostrum samples were stored at $-20^{\circ} \mathrm{C}$ for further analysis.

\section{Processing of colostrum}

\section{Colostrum powder}

Glass Spray Drier (Milk-Tech Engineers) was used to make spray dried cow and buffalo colostrum powder. Based on preliminary studies, colostrum powder $(\mathrm{CP})$ was prepared by adopting $160 / 80^{\circ} \mathrm{C}$ - inlet/outlet air temperature and stored at room temperature.

\section{Insolubility index}

The insolubility index was determined as prescribed in IDF (1988) by adding $10 \mathrm{~g}$ of colostrum powder to $100 \mathrm{ml}$ of water at $24 \circ \mathrm{C} \pm 0 .{ }^{\circ} \mathrm{C}$ with high speed mixing for 90 seconds after adding defoaming agent (octyl alcohol or diglycol laurate). The reconstituted milk was left to stand for $15 \mathrm{~min}$ and after stirring, it was filled in $50 \mathrm{ml}$ centrifuge tubes. It was centrifuged and supernatant was removed. It was diluted with water to $50 \mathrm{ml}$ and recentrifuged at $900 \mathrm{rpm}$ for $5 \mathrm{~min}$. The amount of sediment in tubes was taken in $\mathrm{ml}$ and expressed as insolubility index.

\section{Bulk density}

Bulk density of spray dried colostrum was measured as per the method given in GEA Niro Analytical Methods for Dry Milk Products, GEA Process Engineering A/S, Denmark by using Thermonic bulk density apparatus (Campbell electronics, Mumbai).

For measuring the bulk density of spray dried colostrum, a $50 \mathrm{~mL}$ glass measuring cylinder without top was weighed. It was filled up to $50 \mathrm{~mL}$ mark with powder using a spoon. The weight of the powder was recorded and loose bulk density was calculated using below 
mentioned formula and expressed as $\mathrm{g} \mathrm{mL}^{-1}$.

Bulk Density $\left(\mathrm{g} \mathrm{mL}^{-1}\right)=$ Weight of the powder / volume

Subsequently after closing the cylinder with rubber stopper, it was tapped 100 times. The volume of the powder in the cylinder was recorded and packed bulk density $\left(\mathrm{g} \mathrm{mL}^{-1}\right)$ was calculated using same formula above.

\section{Water activity}

The Novasina lab touch water activity meter was used to determine the water activity of the Colostrum powder samples. Sample cup wasfilled up to half of its volume with sample and placed into water activity meter after well setting and calibration. Readings were displayed automatically after 5 minutes on the screen and expressed as $\mathrm{a}_{\mathrm{w}}$.

\section{Texture analyser}

The hardness of the powder were analysed by TA.XT Plus texture analyser (Microstable systems). Physical product characteristic such as hardness, adhesiveness of the food is measured.

Texture analyser settings and parameters: Sequence Title: TPA 1 T.A. Variable No: 1: Compression Pre-Test Speed: $1.00 \mathrm{~mm} / \mathrm{sec}$ Test Speed: $5.00 \mathrm{~mm} / \mathrm{sec}$ Post-Test Speed: $5.00 \mathrm{~mm} / \mathrm{sec}$ T.A. Variable No: 5: $0.0 \mathrm{~g}$ Distance: $10.000 \mathrm{~mm}$ Strain: $75.0 \%$ Trigger Type: Auto (Force) Trigger Force: $5.0 \mathrm{~g}$ Probe: PCC; PCC Batch: TPA TEST Points per second: 200 Test Run by: MVC

\section{Microbial analysis}

Total viable count (TVC) and coliform counts of samples were determined by the method described by American Public Health Association (APHA, 1984). 10g of the colostrum powder was added with appropriate diluent and it is blended and homogenised for $2-5 \mathrm{~min} .1 \mathrm{ml}$ of this primary dilution is added into sterile petriplates in duplicate. Serial dilution was performed at $10^{-2}, 10^{-3}, 10^{-4}$ for TVC. Add $1 \mathrm{ml}$ from each dilution in respective petri plates. Pour the sterile molten plate count agar. Allow the plate to solidify. Invert the plates and incubate at $37^{\circ} \mathrm{C}$ for 48 hours

$10 \mathrm{~g}$ of the colostrum powder was added with appropriate diluent and it is blended and homogenised for $2-5 \mathrm{~min}$. $1 \mathrm{ml}$ of this primary dilution is added into sterile petriplates in duplicate. Serial dilution was performed $\left(10^{-2}\right)$. Pour the sterile molten violet red bile agar. Allow the plate to solidify. Invert the plates and incubate at $35^{\circ} \mathrm{C}$ for $18-24$ hours. The Media used were from Hi-Media, Mumbai.

\section{Statistical analysis}

The results from all of the tests were calculated as mean \pm SE obtained from average of six trials. Analyses were performed using IBM SPSS ${ }^{\circledR} 20.0$ for Windows ${ }^{\circledR}$ software as per the standard procedure of Snedecor and Cochran, 1989.

\section{Results and Discussion}

Insolubility index were observed as $0.10 \pm 0.013$ and $0.10 \pm 0.014 \mathrm{ml}$ and $0.15 \pm 0.013$ and $0.10 \pm 0.014 \mathrm{ml}$ for $1 \mathrm{st}$ and $2 \mathrm{nd}$ day milking of cow and buffalo colostrum powder respectively. According to Indian Standard Institution the maximum insolubility index of spray dried skim milk powder should be $2.0 \mathrm{ml}$. Hence, the result obtained in present study was within the limit.

Bulk density was $0.425 \pm 0.001$ and $0.421 \pm 0.001 \mathrm{~g} / \mathrm{m} 3$ for 1 st and $2 \mathrm{nd}$ day cow colostrum powder, whereas, $0.454 \pm 0.002$ and 
$0.450 \pm 0.001 \mathrm{~g} / \mathrm{m} 3$ for buffalo colostrum powder. The results obtained were closely related to the findings of Upadhyay (1989). As per the study of Upadhyay (1989), the bulk density of normal spray dried powder varies between $0.5-0.8 \mathrm{~g} / \mathrm{ml}$. The result of Bulk density and Insolubility index is shown in table 1 .

The water activity for cow colostrum powder on initial day storage was $0.556 \pm 0.001$ and $0.557 \pm 0.001$ while, the level for final day of storage were $0.550 \pm 0.009$ and $0.550 \pm 0.001$ respectively. For buffalo colostrum powder on initial day storage were $0.550 \pm 0.003$ and
$0.551 \pm 0.001$ while, the level for final day storage were $0.549 \pm 0.000$ and $0.551 \pm 0.001$ respectively (Table 2). Statistical analysis revealed that there is no significant difference in initial and final day for buffalo colostrum powder but in cow colostrum powder it showed significant difference. It was demonstrated that an increase in equilibrium moisture content was very small in the range of water activity 0.1 to 0.9 . Higher levels of water activity than 0.9 resulted in a marked increase of equilibrium moisture content and susceptibility to spoilage by microoraganisms (Stencl, 1999).

Table.1

\begin{tabular}{|c|c|c|c|c|c|c|}
\hline \multirow{3}{*}{$\begin{array}{l}\text { Physical } \\
\text { properties }\end{array}$} & \multicolumn{3}{|c|}{ Cow colostrum powder } & \multicolumn{3}{|c|}{ Buffalo colostrum powder } \\
\hline & \multicolumn{2}{|c|}{ Days } & \multirow[t]{2}{*}{ F Value } & \multicolumn{2}{|c|}{ Days } & \multirow[t]{2}{*}{$F$ value } \\
\hline & 1 & 2 & & 1 & 2 & \\
\hline $\begin{array}{l}\text { Insolubility } \\
\text { index }\end{array}$ & $0.10 \pm 0.013^{a}$ & $0.10 \pm 0.014$ & $0.78^{\mathrm{NS}}$ & $0.15 \pm 0.013^{b}$ & $0.10 \pm 0.014^{\mathrm{a}}$ & $0.025^{*}$ \\
\hline Bulk density & $0.425 \pm 0.001^{\mathrm{b}}$ & $0.421 \pm 0.001^{\mathrm{a}}$ & $0.093^{*}$ & $0.454 \pm 0.002^{\mathrm{a}}$ & $0.450 \pm 0.001^{\mathrm{a}}$ & $0.082 *$ \\
\hline
\end{tabular}

@ Average of six trials; NS-Non-Significant $(\mathrm{P}>0.05$; * - Significant $(\mathrm{P}<0.05)$, Mean Values bearing different superscripts in a row differ significantly

Table.2

\begin{tabular}{|c|c|c|c|c|c|c|}
\hline Parameters & \multicolumn{3}{|c|}{ Cow colostrum powder } & \multicolumn{3}{c|}{ Buffalo colostrum powder } \\
\hline Days & $\mathbf{1}$ & $\mathbf{2}$ & F value & $\mathbf{1}$ & $\mathbf{2}$ & F value \\
\hline Initial day $\left(\mathrm{A}_{\mathrm{w}}\right)$ & $0.556 \pm 0.001^{\mathrm{aB}}$ & $0.557 \pm 0.001^{\mathrm{bB}}$ & $0.754^{\mathrm{NS}}$ & $0.550 \pm 0.003^{\mathrm{aA}}$ & $0.551 \pm 0.001^{\mathrm{aA}}$ & $0.429^{\mathrm{NS}}$ \\
\hline Final day $\left(\mathrm{A}_{\mathrm{w}}\right)$ & $0.550 \pm 0.009^{\mathrm{aA}}$ & $0.550 \pm 0.001^{\mathrm{aA}}$ & $1.00^{\mathrm{NS}}$ & $0.549 \pm 0.000^{\mathrm{aA}}$ & $0.551 \pm 0.00^{\mathrm{bA}}$ & $0.357^{\mathrm{NS}}$ \\
\hline F value & $0.014^{*}$ & $0.011^{*}$ & & $0.625^{\mathrm{NS}}$ & $1.00^{\mathrm{NS}}$ & \\
\hline
\end{tabular}

@ Average of six trials; NS-Non-Significant $(\mathrm{P}>0.05) ; *$ - Significant $(\mathrm{P}<0.05)$; Mean Values bearing different lower case superscripts in a row differ significantly, Mean Values bearing different upper case superscripts in a column differ significantly.

Table.3

\begin{tabular}{|c|c|c|c|c|c|c|c|c|c|}
\hline \multirow{3}{*}{$\begin{array}{c}\text { Microbial } \\
\text { analysis } \\
\left(\log _{10} \mathrm{cfu} / \mathrm{ml}\right)\end{array}$} & \multirow[t]{3}{*}{ Days } & \multicolumn{4}{|c|}{ Cow colostrum powder } & \multicolumn{4}{|c|}{ Buffalo colostrum powder } \\
\hline & & \multicolumn{3}{|c|}{ Storage period(in months) } & \multirow{2}{*}{$\begin{array}{c}\mathbf{F} \\
\text { value }\end{array}$} & \multicolumn{3}{|c|}{ Storage period(in months) } & \multirow{2}{*}{$\begin{array}{c}\mathbf{F} \\
\text { value }\end{array}$} \\
\hline & & 1 & 3 & 6 & & 1 & 3 & 6 & \\
\hline \multirow{2}{*}{$\begin{array}{l}\text { Total viable } \\
\text { count }\end{array}$} & 1 & $1.5 \pm 0.05$ & $1.57 \pm 0.09$ & $1.65 \pm 0.15$ & $0.12^{\mathrm{NS}}$ & $1.48 \pm 0.04$ & $1.55 \pm 0.08$ & $1.63 \pm 0.11$ & $1.00^{\mathrm{NS}}$ \\
\hline & 2 & $1.52 \pm 0.06$ & $1.58 \pm 0.03$ & $1.67 \pm 0.10$ & $1.05^{\mathrm{NS}}$ & $1.55 \pm 0.10$ & $1.59 \pm 0.05$ & $1.66 \pm 0.04$ & $0.19^{\mathrm{NS}}$ \\
\hline \multirow{2}{*}{$\begin{array}{l}\text { Coliform } \\
\text { count }\end{array}$} & 1 & \multirow{2}{*}{\multicolumn{3}{|c|}{ Nil }} & - & \multirow{2}{*}{\multicolumn{3}{|c|}{ Nil }} & - \\
\hline & 2 & & & & & & & & \\
\hline
\end{tabular}

@ Average of six trials; NS-Non-Significant $(\mathrm{P}>0.05)$ 
Fig.1

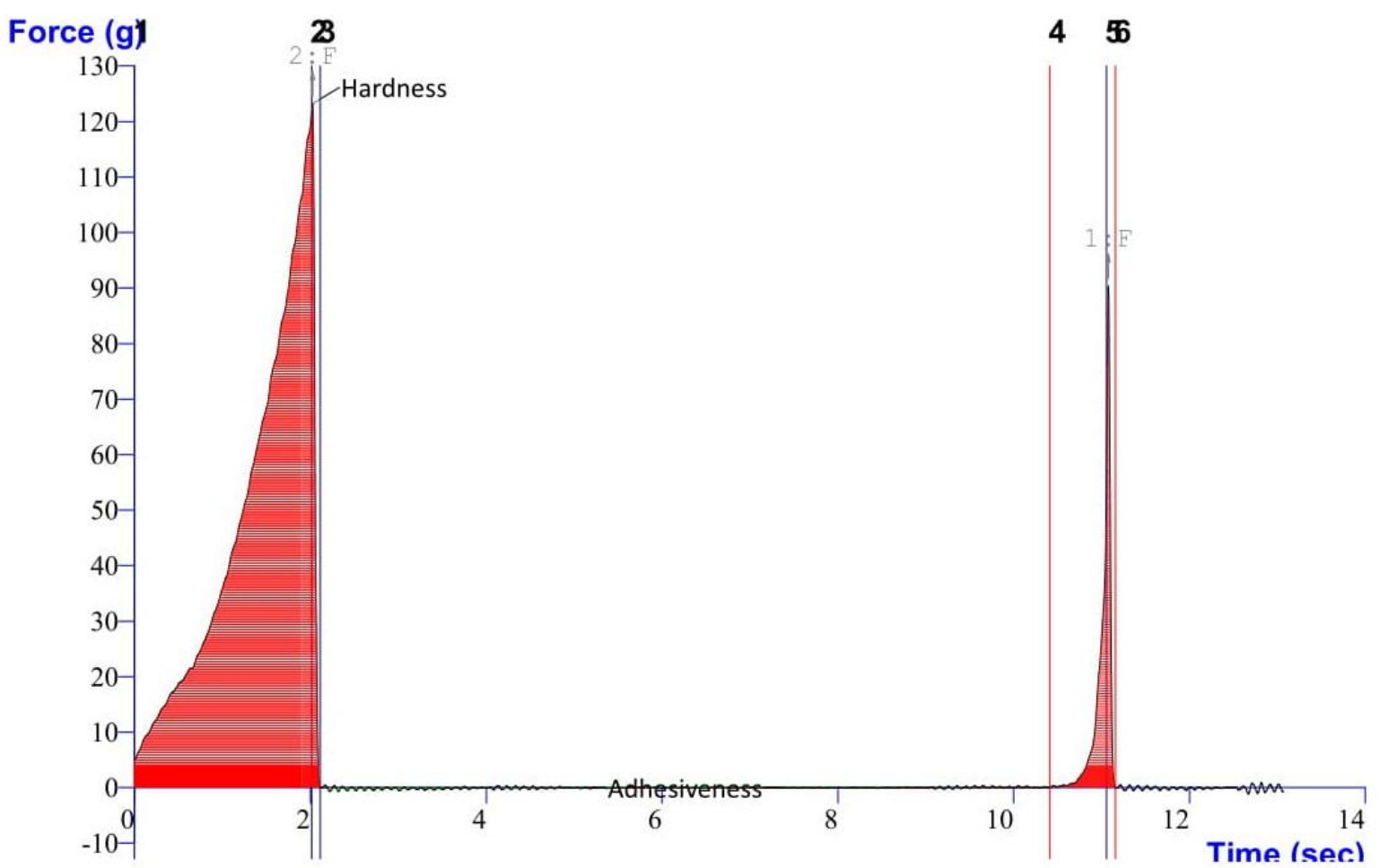

There was no spoilage in the spray dried colostrum powder during the storage period as the water activity of above said powder was 0.5 which was within the range of 0.1 0.9 . The TVC for cow colostrum powder during different storage periods viz. 1, 3 and 6 months were $1.5 \pm 0.05,1.57 \pm 0.09,1.65 \pm 0.15$ and $1.52 \pm 0.06, \quad 1.58 \pm 0.03, \quad 1.67 \pm 0.10$ $\log _{10} \mathrm{cfu} / \mathrm{ml}$ for first and second days respectively, whereas, for the buffalo colostrum powder $1.48 \pm 0.04,1.55 \pm 0.08$, $1.63 \pm 0.11$ and $1.55 \pm 0.10, \quad 1.59 \pm 0.05$, $1.66 \pm 0.04 \log _{10} \mathrm{cfu} / \mathrm{ml}$ for first and second day respectively. The TVC count for cow and buffalo colostrum showed increasing trend during storage period. It is due to storage of colostrum powder at room temperature. But statistical analysis revealed no significant difference during different storage period with regard to TVC of spray dried colostrum powder. Coliform were not detected in spray dried colostrum powder. This is due to high processing temperature maintained in spray drier process. There are no specific standards for spray dried whole colostrum powder. The final quality of the colostrum powder depends on the initial quality of the colostrum collected from the farms and the influence of the processing parameters (heat induced changes, fractionation of components etc.). Specific standards on the microbial quality of the colostrum powders are not available at present. The standards are to be established for these products. Specifications of some of the colostrum manufacturing companies' product available in market were $10,000 \mathrm{org} / \mathrm{g}$ for standard plate count and absent in $0.1 \mathrm{~g}$ for coliforms. The result for TVC and coliform are shown in table 3

In conclusion, colostrum powder was prepared by spray drying the whole colostrum with inlet and outlet temperature of $160^{\circ} \mathrm{C}$ and $80^{\circ} \mathrm{C}$ respectively. The yield of cow and buffalo colostrum powder was 12 and 15 per cent respectively. Hence, the surplus 
colostrum was utilized by spray drying method and found to have no changes in physical and microbial parameters during storage at room temperature.

\section{Acknowledgement}

The authors acknowledge the help provided by the Department of Food Processing Technology and Department of Food Safety and Quality Assurance, College of Food and Dairy Technology and Department of Livestock Products Technology, Madras Veterinary College, TANUVAS for utilizing the lab facilities for analysis physical parameters and quality control analysis.

\section{References}

APHA (American Public Health Association). 1992. Standard methods for the examination of dairy products, 16th edit., 1992, Washington, U.S.A

Carid, M. (2003). Milk powders-types and manufacture. In Encyclopedia of dairy sciences, H. Roginski, J.W. Fuquay and P.F. Fox (Eds.), London, UK: Academic Press. pp 1869-1874.

Chelack B.J., Morley P.S. and Haines D.M. (1993). Evaluation of methods for dehydration of bovine colostrum for total replacement of normal colostrum incalves. Can Vet J. 34(7):407-412.

International Dairy Federation (IDF). 1988. Determinationdel'indiced'insolubilite. Standard No. 129A.

GEA Niro Analytical Methods for Dry Milk Products (2008). Www.niro.com/
niro/CMSDoc.nsf/webDoc/ndkw6uqc $\mathrm{mb}$, accessed on 22 January 2008

Kelly, G. S. (2003). Bovine colostrums: a review of clinical uses. Alternative Medicine Review, 8(4).

Quigley, J. D., Fike, D. L., Egerton, M. N., Drewry, J. J., and Arthington, J. D. 1998. Effects of a colostrum replacement product derived from serum on immunoglobulin $G$ absorption by calves. J Dairy Sci, 81(7): 1936-1939

Snedecor, G. W., \&W G Cochran,. 1989. Statistical methods, 8thEdn. Ames: Iowa State Univ. Press Iowa.

Štencl, J. 1999. Water activity of skimmed milk powder in the temperature range of 20-45 C. Acta Veterinaria Brno, 68(3):209-215.

Tom R. Philips, 1998.Canine immune system. Encyclopedia of Immunology (Second edition) 411-414.

Upadhyay, K.G. 1989 Properties of milk powders, their significance and processing drying variables influencing such properties. Refresher course compendium on drying of milk and milk products. SMC College of Dairy Science, $5^{\text {th }}-15$ th June, 1989. pp. 69-93.

Xanthou, M., Bines, J. and Walker, W.A. 1995 Human milk and intestinal host defense in newborns: An update. Adv. Pediatr. 42:171-208.

$\mathrm{Xu}, \mathrm{R}$. J. 1996. Development of the newborn GI tract and its relation to colostrum/milk intake: a review. Reproduction, Fertility and Development, 8(1): 35-48.

\section{How to cite this article:}

Sahana, N., D. Ramasamy, T.R. Pugazhenthi and Manikkavasagan, I. 2018. Studies on Physical and Microbial Parameters of Bovine Colostrum Powder. Int.J.Curr.Microbiol.App.Sci. 7(08): 2766-2771. doi: https://doi.org/10.20546/ijcmas.2018.708.290 